\title{
PENINGKATAN PRODUKSI BAWANG MERAH (Allium ascalonicum L.) MELALUI SELEKSI KLON BERULANG SEDERHANA PADA SISTEM BUDIDAYA ORGANIK DI DESA TAMAN AYU
}

\author{
Wayan Wangiyana ${ }^{1 *}$, I Ketut Ngawit ${ }^{1}$, Akhmad Zubaidi $^{1}$, Nihla Farida ${ }^{1}$ \\ 1) Program Studi Agroekoteknologi Universitas Mataram \\ Jalan Majapahit Nomor 62, Kota Mataram, Provinsi Nusa Tenggara Barat \\ *) Alamat korespondensi: w.wangiyana@unram.ac.id
}

\begin{abstract}
ABSTRAK
Permasalahan utama yang dihadapi petani bawang merah di wilayah kawasan lereng Gunung Malang, Desa Taman Ayu, Kecamatan Gerung, Kabupaten Lombok Barat adalah semakin rendahnya produktivitas tanah akibat kurangnya pemanfaatan pupuk organik, mahalnya pengadaan umbi bibit bawang, dan masih rendahnya kemampuan kewirausahaan petani. Tujuan dari pelaksanaan kegiatan pengabdian kepada masyarkaat ini adalah untuk meningkatkan produktifitas para petani di Desa Taman Ayu dalam memproduksi bawang merah. Metode kegiatan adalah pelatihan dan kaji tindak, berupa pembuatan demplot dan pendampingan petani dalam kegiatan upaya peningkatan produktivitas bawang merah dengan aplikasi pupuk organik, pengadaan umbi bibit bawang merah melalui seleksi berulang sederhana dan pendampingan pengolahan limbah kandang ternak dan limbah pertanian menjadi pupuk organik. Berdasarkan hasil evaluasi seluruh kegiatan, masukan teknologi organik yang didemplotkan memberikan hasil bawang merah dengan keuntungan yang lebih tinggi, yang mencapai $\mathrm{Rp} 53.560 .000,-\mathrm{s} / \mathrm{d} \mathrm{Rp} 63.360 .000,-$ pada musim tanam ke-I dan mencapai Rp 79.364.000,- s/d 91.369.000,- pada musim tanam ke-II, dengan BC-ratio mencapai 1,86-2,23, dibandingkan dengan pertanaman non-demplot. Selain dapat memberikan nilai tambah secara ekonomi, aplikasi pupuk organik sangat menguntungkan secara agronomis karena dapat menjaga kesuburan tanah dalam jangka panjang secara berkelanjutan.
\end{abstract}

Kata kunci: bawang merah, demplot, organik, pupuk kandang, seleksi berulang 


\section{PENDAHULUAN}

Salah satu sentra produksi pertanian khususnya produk hortikultura di kabupaten Lombok Barat, Nusa Tenggara Barat (NTB) adalah di kawasan Lereng Gunung Malang, tepatnya di Desa Bongor dan Kebun Ayu, Kecamatan Gerung, Lombok Barat NTB. Produk unggulan yang terus dikembangkan petani setempat adalah bawang merah dalam bentuk produk umbi bibit dan umbi konsumsi. Berdasarkan laporan Dinas Pertanian Tanaman Pangan NTB (2008), luas areal penanaman tanaman bawang merah di wilayah ini mencapai 765,78 ha setiap tahun dengan sistem pola tanam tiga (3) kali penanaman diselingi satu (1) kali tanaman padi atau sayur-sayuran dan buah-buahan semusim sebagai tanaman sela. Tanaman buah dan sayuran semusim yang umum diusahakan di wilayah ini antara lain : Kul Bulat, Sawi, Seladri, Kacang Panjang, Melon dan Semangka. Selain tanaman hortikultura tersebut, di wilayah ini juga sebagai sentra produksi ternak ayam pejantan, ayam kampung, itik dan ternak ruminasia terutama sapi Bali, untuk memenuhi permintaan restoran dan rumah makan khas "Taliwang" yang tersebar di wilayah Lombok Barat dan Tujuan Wisata Pantai Senggigi (Ngawit et al., 2000).
Rata-rata produksi bawang merah untuk produk umbi bibit mencapai 4,50 ton/ha dan untuk umbi konsumsi 5,75 ton/ha. Produksi ini cukup stabil dari tahun ketahun, namun karena kebutuhan saprodi semakin meningkat dan juga semakin mahalnya harga pupuk dan obatobatan kimia, menyebabkan keuntungan yang diterima petani pengusaha semakin menipis (Ngawit et al., 2000). Terlebih-lebih lagi dalam proses produksi umbi bibit, yang memerlukan masukan teknologi budidaya dan pasca panen khusus, tentu akan menambah biaya produksi. Umbi bibit bawang merah di wilayah ini yang telah dikenal sebagai varietas Ampenan telah cukup populer di kalangan petani bawang terutama di daerah Jawa, Bali, dan Pulau Sumbawa. Berdasarkan data perdagangan antar pulau, lebih dari $80 \%$ total produksi umbi bibit bawang merah di wilayah ini di pasarkan ke Bali, Sumbawa dan Bima dengan permintaan pasar dari tahun ke tahun terus meningkat (Dinas Perindustrian dan Perdagangan Lombok Barat NTB, 2008).

Dalam upaya pengembangan usaha agribisnis di wilayah ini, yang menjadi kendala adalah masih rendahnya potensi sumber daya manusia pengelolanya dan rendahnya kemampuan permodalan petani pengusaha (Kusnarta et al., 1998). Karena itu produksi komuditi 
unggulan tidak bisa stabil dan kontinyu. Kendala lain yang selalu menjadi hambatan bagi petani untuk memproduksi komuditi unggulan seperti umbi bibit bawang merah, adalah semakin menurunnya produktivitas tanah. Petani semakin ketergantungan terhadap pupuk dan obat-obatan kimia sehingga biaya produksi semakin meningkat dari tahun ketahun, sementara di sisi lain harga produk petani kurang stabil. Fakta membuktikan bahwa sistem pertanian moderen yang secara intensif menggunakan pupuk dan obat-obatan kimia telah memutuskan mata rantai proses dekomposisi di dalam tanah. Akibatnya pengadaan unsur hara secara alami melalui proses dekomposisi tidak berlangsung normal sehingga tanaman kurang menghasilkan panen yang baik. Kualitas produk umbi bibit semakin menurun; hal ini ditandai dengan menurunnya fiabilitas, umur massa simpan semakin pendek dan mudah mayang. Penyebab utamanya yang tampak adalah, kerusakan tekstur dan struktur tanah, kebalnya hama dan orgenisme penyebab peyakit tanaman dan terakumulasinya residu pestisida dan pupuk di dalam tanah dan air. Kasus terhentinya produksi Bawang Putih di wilayah Desa Sembalun, Kabupaten Lombok Timur NTB, merupakan bukti nyata dampak dari ketergantunmgan pupuk dan obatobatan kimia secara berlebihan
(Kusnarta, 1996; Wood et al., 1992; Ngawit et al., 1998).

Solusi yang ditawarkan untuk menangani masalah ini adalah secara bertahap meninggalkan teknologi pertanian konvensional dan kembali ke sistem budidaya organik sebagai bagian dari sistem pertanian berkelanjutan. Salah satu unsur yang mendukung terlaksananya sistem ini adalah dengan memanfaatkan sistem hubungan timbal balik antara tanaman dengan ternak untuk mendapatkan bahan baku pembenah tanah dengan memanfaatkan teknologi modern berupa mikroba probiotik. Sedangkan untuk mengatasi permasalahan semakin menurunnya kualitas produk umbi bibit, dilakukan dengan Metode "Seleksi Klon Sederhana Secara Berulang" yang telah dilakukan sejak tahun 2000. Seleksi ini didukung dengan tindakan agronomis terutama mengenai pengaturan pola tanam, penerapan sistem budidaya organik dan penanganan pascapanen yang baik. Dalam sistem budidaya organik diupayakan sebesar-besarnya pemanfaatan pupuk alami, sedangkan penggunaan pupuk buatan dan pestisida sintetik secara bertahap ditinggalkan. Pupuk organik yang digunakan untuk tanaman bawang merah diproduksi oleh kelompok peternak dalam bentuk Briket Kompos Plus, dengan bahan baku limbah kandang ternak ayam, ternak sapi, dedak dan jerami dengan 
memanfaatkan bahan dekomposer aktif jamur Thricoderma harzanum dan Arthrobotrys dactyloides.

Perbaikan sifat-sifat populasi umbi bibit bawang merah menyangkut perbaikan antar populasi dan dalam populasi. Perbaikan tersebut dapat dilakukan melalui seleksi klon berulang sederhana (fenotipe). Tahap kegiatan seleksi tersebut, yaitu menanam populasi dasar untuk membuat $\mathrm{C} 1$, evaluasi $\mathrm{C} 1$ dan rekombinasi di antara C1 terpilih. Evaluasi pada seleksi ini adalah penampilan C1 sendiri. Seleksi ini merupakan perbaikan dari seleksi massa (Dahlan 1998). Oleh karena itu, seleksi klon berulang sederhana yang dilaksanakan dalam setiap siklus meliputi kegiatan penanaman populasi dasar dan melakukan "selfing" tanaman terpilih (50\% dari seluruh populasi) pada musim pertama dan melakukan rekomendasi terhadap umbi terpilih pada musim kedua. Seleksi ini berdasarkan standar umbi bibit, daya hasil dan ketahanan terhadap penyakit embun upas. Mengingat varietas unggul yang dikehendaki, yaitu varietas yang memiliki sifat-sifat cepat tumbuh, ukuran umbi bibit seragam, bernas, tahan disimpan lebih lama, daya hasil tinggi dan tahan terhadap penyakit embun upas. Agar dapat dilakukan "selfing" terhadap tanaman terpilih, maka perbaikan sifat kecepatan bertunas umbi bibit, dilakukan melalui sifat umur keluar tunas; daya hasil melalui jumlah siung dan berat umbi per rumpun dari tanaman hasil "selfing"; dan ketahanan terhadap penyakit embun upas dilakukan pengujian di laboratorium dan rumah kaca terhadap hasil "selfing".

Seleksi klon sederhana tersebut telah dilaksanakan, sejak tahun 2008 (Budianto et al., 2008). Berdasarkan hasil seleksi tersebut telah didapat "Properti varietas umbi bibit bawang merah khas Bongor". Namun demikian tingkat stabilitas, adaptasi dan daya hasil aktual di tingkat petani belum diketahui. Sehubungan dengan hal ini maka akan dilakukan rangkaian pembinaan terhadap petani untuk memproduksi umbi bibit bawang merah khas bongor ini, sehingga menjadi laik teknis dan laik komersial. Hal ini penting mengingat, permintaan akan umbi bibit bawang merah hasil produksi ini dari tahun ke tahun terus meningkat sementara produksi masih terbatas. Oleh karena itu sangat penting dilaksanakan kegiatan upaya peningkatan produksi umbi bibit bawang merah ini melalui pemanfaatan teknologi produksi yang berwawasan agribisnis dan berkelanjutan sehingga dapat dihasilkan umbi bibit bawang merah dengan kualitas dan kontinyuitas produksi yang stabil.

Tujuan dari kegiatan pengabdian masyarakat ini adalah untuk memperkenalkan teknik pembuatan pupuk organik dari limbah 
kandang sapi (sisa-sisa pakan dan kotoran sapi) yang difermentasi dengan decomposer EM-4 melalui proses pelatihan petani, dan mendiseminasikan teknologi produksi umbi bibit bawang merah melalui pembuatan demplot, yang diakhiri dengan pelatihan analisis usahatani dari hasil panen umbi bibit bawang merah, sehingga petani dapat menghitung keuntungan usahatani umbi bibit bawang merah.

\section{METODE KEGIATAN}

Kegiatan pengabdian

masyarakat ini dilaksanakan di wilayah desa Taman Ayu, kecamatan Gerung, kabupaten Lombok Barat, dengan pelaksanaan demplot selama dua musim tanam bawang merah di dusun Bongor dan dusun Peseng.

\section{Kerangka Pemecahan Masalah}

Menyimak kondisi alam setempat dan permasalahan yang dihadapi masyarakat tani di wilayah obyek kegiatan maka langlah-langkah yang dilaksanakan untuk penyelesaian masalah yang dihadapi adalah :

1. Langkah pertama melakukan observasi lapang, untuk mendapatkan informasi akurat mengenai kesiapan petani bawang merah sebagai mitra usaha dan mau menerima inovasi/teknologi tepat guna serta bekerjasama dengan Tim Pelaksana Proyek.

2. Setelah mendata permasalahan riil dari petani sebagai calon pengusaha mikro, maka dilakukan pelatihan secara intensif terhadap petani sebagai calon peserta program, terutama mengenai sistem usahatani yang diterapkan dan paket teknologi yang diaplikasikan dalam setiap usaha produksi bawang merah yang diintroduksikan. Pupuk organik yang merupakan bagian dari teknologi yang diintroduksi disiapkan oleh petani melalui pelatihan pembuatan kompos menggunakan limbah kandang sapi (kotoran sapi dan sisa-sisa pakan) yang difermentasi dengan dekomposer EM-4.

3. Sebagai tindak lanjut, maka dilakukan program Kaji Tindak, tentang aplikasi model usahatani produksi umbi bibit bawang merah, yang dibentuk sebagai usaha agribisnis dengan penerapan teknik budidaya organik. Model usaha agribisnis ini terdiri atas beberapa variabel komponen masukan teknologi yaitu:

a. Pengelolaan tanah; melalui pengolahan tanah minimum, yaitu satu kali bajak dan satu kali garu, pemupukan dengan pupuk kandang dosis $30-40$ ton/ha yang telah dikomposkan sempurna dengan aktivator dekomposer Em-4 AgronemosPlus dan Koma. Pemupukan Nitrogen dilakukan seminimal mungkin melalaui aplikasi pupuk mejemuk NPK dengan 
pemberian secara bertahap sebanyak dua kali, yaitu setengah dosis anjuran diberikan saat pengolahan tanah dan sisanya setengah dosis diberikan saat tanaman berumur 28 hari.

b. Pola tanam yang diterapkan adalah sistem tumpang gilir yang terdiri atas 2 kali bawang (Maret/April dan Juni/Juli) kemudian disusul Padi dan Palawija lainnya. Teknologi budidaya yang diterapkan adalah yang ramah lingkungan yang menjamin model produksi usahatani berkelanjutan. Tanaman bawang merah sebagai tanaman utama diusahakan secara intensif yang bertumpu pada budidaya organik, yaitu pengelolaan ekosistem tanaman dengan mengutamakan penggunaan bahan alami (pupuk organik/kompos dan pestisida hayati) dan menekan seminimal mungkin penggunaan pupuk anorganik terutama urea dan pestisida kimiawi. Tujuan utamanya adalah agar produk umbi bibit bawang merah yang dihasilkan berkualitas tinggi dan memeliki umur masa simpan lebih lama yaitu tetap bernas meskipun di simpan lebih dari satu tahun.

c. Program kaji tindak selanjutnya berupa pelatihan dan pendampingan secara langsung tim pelaksana proyek terhadap petani mitra mengenai teknik penanaman bawang untuk produk umbi bibit, seleksi berulang sederhana berdasarkan kreteria sifat-sifat unggul umbi bibit, panen dan penanganan erta pengolahan limbah pertanian dan kandang ternak menjadi pupuk organik yang berkualitas. Pengandalian hama ulat grayak (Laphygma exigua) dilakukan cara biologis dengan teknik penanaman tanaman pagar (bemper) disekeliling guludan tanaman bawang merah menggunakan tanaman kacang tanah. Tanaman bemper (kacang tanah) ditanam saat tanaman bawang merah berumur 7 hari, dengan jarak tanam $20 \mathrm{~cm}$. Proses pengolahan seresah tanaman dan limbah kandang ternak menjadi pupuk organik dilakukan dengan teknik pengomposan secara bertahap, yaitu pengomposan secara alami dalam wadah/lubanglubang selama beberapa waktu sampai terbentuk kompos, selanjutnya kompos tersebut diuraikan kembali dengan bantuan mikrobia decomposer sampai menjadi pupuk organik. Produk pupuk organik berkualitas ditentukan berdasarkan $\mathrm{C} / \mathrm{N}$-ratio, $\mathrm{pH}$, 
kadar air, kandungan nutriennya dan kemampuannya meningkatkan status kesuburan tanah serta hasil tanaman secara aktual.

\section{Metode Penyelesaian Masalahan}

Metode pendekatan yang diterapkan untuk penyelesaian permasalahan dalam pengelolaan model produksi yang direncanakan adalah Program Kaji Tindak Partisipatif (Participatory Action Program), yaitu tim pelaksana proyek melibatkan petani sebagai mitra usaha agribisnis sejak awal pelaksanaan sampai evaluasi proyek. Pendekatan yang dilakukan adalah dari bawah dan dari atas (Bottom-up and top down approach) dengan memperhatikan pengetahuan, keterampilan dan kearifan para petani mitra (indigenous knowledge). Masing-masing masukan inovasi/teknologi yang akan diaplikasikan dengan petani mitra, merupakan unit produksi yang bersifat stimulan dan merupakan usaha tambahan dan penyempurnaan dari unit-unit usaha yang telah ada. Karena itu, petani yang dijadikan mitra usaha adalah pengusaha kecil yang mau dan siap bekerjasama berdasarkan pola kemitraan yang saling menguntungkan, dengan kreteria sebagai berikut :

1. Tidak terserap sebagai tenaga kerja di perusahaan swasta atau sebagai pegawai negeri.
2. Memiliki motivasi dan kemauan yang tinggi untuk mengembangkan usaha agribisnisnya.

3. Sanggup menyediakan lahan untuk aplikasi masing-masing model produksi sekurang-kurangnya 0,5 ha dengan fasilitas jalan yang mudah dijangkau.

4. Bersedia dan sanggup bekerjasama dengan Tim Pelaksana Program $I_{b} M$.

5. Sanggup melakukan pembebanan biaya berupa pengadaan lahan milik sendiri dan pembagian hasil yang telah disepakati, dengan tim pelaksana kegiatan program $\mathrm{I}_{\mathrm{b}} \mathrm{M}$.

6. Sistem permodalan dan pengembalian keuntungan berdasarkan kesepakatan yang saling menguntungkan.

7. Hasil panen yang diterima tim pelaksana kegiatan $\mathrm{I}_{b} \mathrm{M}$, akan digulirkan kepada petani lain yang berminat di sekitar lokasi kegiatan proyek.

\section{Rancangan Evaluasi}

Supaya dapat diketahui keberhasilan masing-masing unit produksi yang diaplikasikan, pada setiap petani sebagai khalayak sasaran, maka dilakukan evaluasi yang terdiri atas beberapa tahap, yaitu : 1).Tahap pertama, keseriusan dan antusiasme petani khalayak sasaran dalam mengelola usaha taninya; 2). Evaluasi terhadap pelaksanaan masing-masing unit usaha di lapang, terutama terhadap 
nilai ekonomi melalui analisis ekonomi sederhana dengan beberapa parameter, yaitu : Modal investasi, Pendapatan kotor, Keuntungan bersih, BC-ratio, BEP dan keberlanjutan usaha; 3). Evaluasi secara agronomis dilakukan terhadap beberapa variabel, seperti antara lain: Ketahanan masa simpan benih, viabilitas, susut bobot, dan persentase benih rusak.

Sebagai indikator dari keberhasilan pelaksanaan program penerapan ipteks ini adalah: 1). Petani yang dibina telah siap menjadi wirausahawan baru; 2). Petani mitra khalayak sasaran memiliki model produksi usahatani yang berkelanjutan berupa investasi, seperti stok umbi bibit dan perluasan areal tanam; 3). Produk dan omset penjualan komoditi yang diusahakan semakin meningkat; Ada permintaan petani lain untuk menjalin kemitraan baru di sekitar lokasi kegiatan pada setiap akhir siklus, meskipun produk utama yang diusahakan tanaman lain dari yang diintroduksikan.

\section{HASIL DAN PEMBAHASAN}

\section{Kegiatan Pelatihan}

Petani sasaran sangat antusias mengikuti semua rangkaian kegiatan pelatihan, yang terbukti dari semangat kehadiran dan aktivitas mereka dalam mengajukan berbagai pertanyaan. Berdasarkan hasil diskusi diketahui beberapa kendala dan permasalahan pokok yang dihadapi oleh petani antara lain:

1. Tingginya intensitas penggunaan pestisida untuk pengendalian hama dan penyakit.

2. Keadaan tanah yang semakin miskin unsur hara dan bahan organik. Akibatnya dalam setiap pengusahaan tanaman dibutuhkan masukan pupuk dan obat-obatan cukup tinggi agar tanaman tumbuh baik.

3. Penggunaan pupuk anorganik terutama NPK, yang cukup tinggi menambah biaya produksi, mengingat harga pupuk anorganik semakin mahal dam kadangkadang langka saat dibutuhkan petani.

4. Selain masalah hama dan penyakit, pengganggu lain adalah gulma. Setiap pengusahaan tanaman bawang merah, biaya pengendalian gulma yang dialokasikan oleh petani sampai mencapai 10 - $15 \%$ dari total biaya produksi.

\section{Hasil Kaji Tindak di Dusun Bongor}

Persiapan untuk kegiatan kaji tindak (demplot) dalam pelaksanaan kegiatan ini, diawali dengan proses pembuatan pupuk organik dan persiapan tanam untuk memperbanyak bibit stok. Proses pembuatan pupuk organik yang diintroduksikan kepada petani peserta pelatihan diawali dengan pengadaan bahan baku yang dikumpulkan dari 
limbah kandang ternak, seresah tanaman, jerami dan limbah pertanian lainya. Selanjutnya semua bahan tersebut didekomposisikan ke dalam lubang sedcalam 1,5 $\mathrm{m}$ dan setiap minggu sekali diaduk sambil diberi pamor gamping sebanyak $5 \mathrm{~kg}$ setgiap 1 ton bahan. Proses ini berlangsung selama 21 hari, kemudian bahan diangkat dan diayak dengan ayakan bermata saring 2 mesh sehingga didapat bahan berupa kompos. Kompos tersebut selanjutnya didekomposisikan kembali dengan bantuan decomposer biakan murni EM-4 dan Tricorderma harsianum selama 14 hari sehingga dapat diproduksi pupuk organik.

Penanaman

pertama

bertujuan untuk memperbanyak bibit stok hasil seleksi. Kegiatan kaji tindak ini diawali dengan pengolaha tanah dan pembuatan bedenga-bedengan yang berbentuk guludan dengan lebar 1,5 $\mathrm{m}$ dan panjang sesuai dengan lebar petakan sawah. Kemudian dilanjutkan dengan pembuatan selokan antar bedengan dengan kedalaman $30 \mathrm{~cm}$ dan lebar $25 \mathrm{~cm}$. Selanjutnya dilakukan aplikasi pupuk organik yang telah diproduksi teraebut dengan dosis 25 ton/Ha. Diaplikasikan pula pupuk NPK sebagai pupuk dasar dengan dosis $200 \mathrm{~kg}$ urea/ha; $100 \mathrm{~kg} \mathrm{TSP} / \mathrm{ha}$; dan $100 \mathrm{~kg}$ $\mathrm{KCl} / \mathrm{ha}$.

Setelah proses aplikasi bahan pembaik tanah, selanjutnya dilakukan penanaman umbi bibit bawang merah dengan jarak tanam $15 \times 15 \mathrm{~cm}$, dengan menanam satu siung per lubang. Kemudian tanaman diberi mulsa jerami yang menutupi penuh permukaan bedengan dengan ketebalan 10-15 cm. Seminggu setelah penanaman bawang merah, dilakukan penyulaman terhadap umbi bibit yang tidak tumbuh atau busuk.

Evaluasi dilakukan akibat aplikasi pupuk organik terhadap status kesuburan tanah, pertumbuhan dan hasil tanaman bawang merah. Secara rinci hasil beberapa paramater yang dijadikan sebagai tolak ukur evaluasi disajikan pada Tabel 1. Secara visual kenampakan dari pertumbuhan tanaman akibat aplikasi komponen masukan teknologi yang diintroduksikan disajikan pada Gambar 1.

Berdasarkan hasil pengamatan selama periode 4 bulan setelah aplikasi komponen masukan teknologi yang diintroduksikan, ternyata perubahan status kesuburan tanah mengalami perubahan yang cukup berarti (Tabel 1). Perubahan yang cukup mencolok terjadi pada kandungan bahan organik tanah dan populasi cacing tanah, serta pertumbuhan dan hasil tanaman bawang merah.

Berdasarkan hasil evaluasi pelaksanaan kaji tindak di Dusun Bongor, ternyata secara ekonomi pengusahaan tanaman bawang merah yang menekankan pada aplikasi masukan teknologi alami (organik) 
ternyata mampu memeberikan keuntungan yang cukup tinggi, baik pada musim tanam ke-I maupun ke-II. Aplikasi pupuk organi 25 ton/ha dan tampa aplikasi pupuk anorganik hasil bawang merah yang diperoleh tidak berbeda dibandingkan dengan pengusahaan secara konvensional
Pertumbuhan tanaman bawang merah selama tumbuhnya tetap sehat, terlebih lagi selalu disemprot dengan air hangat dan pupuk daun yang sekaligus sebagai upaya pengendalian penyakit embun upas (Gambar 1).

Tabel 1. Perubahan status kesuburan tanah dan hasil bawang merah, setelah aplikasi beberapa komponen masukan teknologi yang diintroduksikan

\begin{tabular}{llc}
\hline No. $\quad$ Variabel Pengamatan & $\begin{array}{c}\text { Sebelum aplikasi } \\
\text { komponen } \\
\text { masukan teknologi }\end{array}$ & $\begin{array}{c}\text { Setelah aplikasi } \\
\text { komponen teknologi } \\
\text { yang diintroduksi }\end{array}$ \\
\hline $1 \quad$ Status kesuburan tanah & & \\
a. pH tanah & 7,70 & 7,20 \\
b. Bahan organik (\%) & 1,20 & 6,05 \\
c. N total (\%) & 0,33 & 0,48 \\
d. K2 $\mathrm{O}$ ppm & 2,41 & 2,46 \\
e. P2O5 ppm & 3,04 & 3,12 \\
f. KTK (me/100g tanah) & 11,46 & 11,86 \\
g. Indeks populasi cacing tanah & 10,02 & 32,88 \\
\hline
\end{tabular}

2 Hasil bawang merah:

\begin{tabular}{|c|c|c|c|}
\hline \multicolumn{2}{|c|}{ Musim Tanam I } & 7,746 ton/ha & 8,467 ton/ha \\
\hline & Musim Tanam II & 7,746 ton/ha & 10,244 ton/ha \\
\hline \multirow[t]{3}{*}{3} & Intensitas Hama Ulat Grayak: & & \\
\hline & Musim Tanam I & $27,68 \%$ & $12,89 \%$ \\
\hline & Musim Tanam II & $27,68 \%$ & $11,22 \%$ \\
\hline
\end{tabular}

Pada pengusahaan tanaman bawang dengan model ini terjadi pengurangan biaya produksi terutama pada biaya pembelian pupuk NPK, obat-obatan untuk pengendalian hama dan penyakit dan pengendalian gulma. Hasil yang diperoleh pada musim tanam yang ke-II, lebih tinggi dibandingkan pada musim tanam yang ke-l. Hal ini diduga berkaitan dengan keadaan iklim terutama curah hujan yang pada musim tanam ke II telah memasuki musim kemarau dan sebagian besar petani telah mengusahakan tanaman palawija setelah tanaman padi. Rata-rata hasil yang diperoleh pada muisim Tanam ke-I 8,467 ton/ha sedangkan pada 
musim tanam ke-Il mencapai 10,224 ton/ha (Tabel 1).
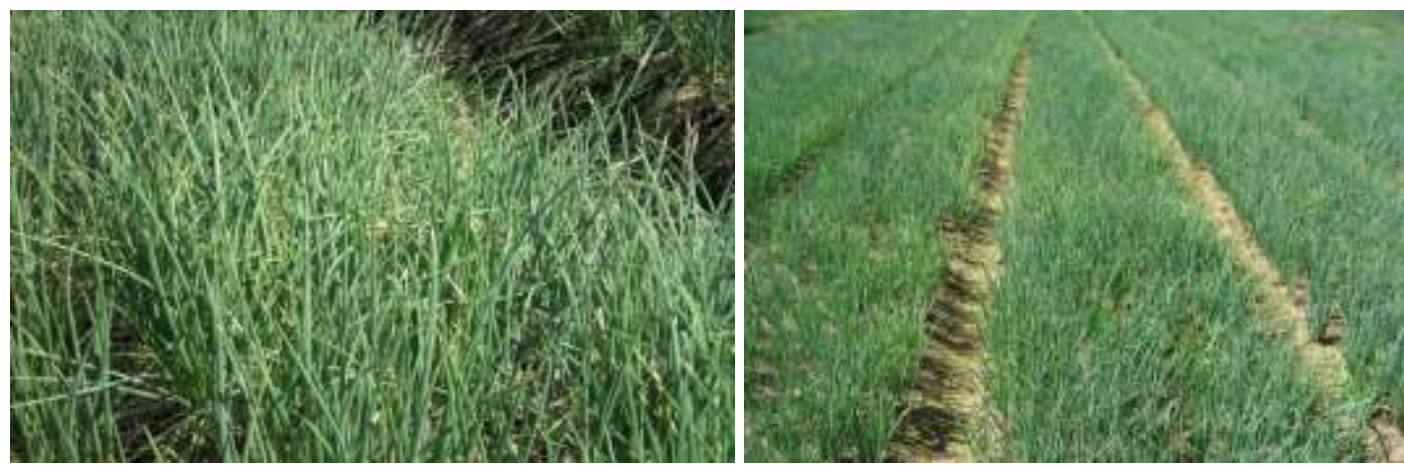

Gambar 1. Pertumbuhan tanaman bawang merah dengan penerapan komponen masukan teknologi yang diintroduksikan (gambar kiri: bawang siap panen) dan (gambar kanan tanaman bawang merah umur 21 hari setelah tanam)

\section{Hasil Kaji Tindak di Dusun Peseng}

Kegiatan kaji tindak ini diawali dengan pengolaha tanah dan pembuatan bedenga-bedengan yang berbentuk guludan dengan lebar 1,5 $\mathrm{m}$ dan panjang sesuai dengan lebar petakan sawah. Kemudian dilanjutkan dengan pembuatan selokan antar bedengan dengan kedalaman $30 \mathrm{~cm}$ dan lebar $25 \mathrm{~cm}$. Selanjutnya dilakukan aplikasi pupuk organik yang telah diproduksi pada kegiatan kaji tindak sebelumnya, dengan dosis 25 ton/Ha. Tidak dilakukan pemupukan dengan pupuk anorganik NPK sebagai pupuk dasar. Setelah proses aplikasi bahan pembaik tanah, selanjutnya dilakukan penanaman umbi bibit bawang merah dengan jarak tanam 15 $x 15 \mathrm{~cm}$, dengan menanam satu siung per lubang. Kemudian tanaman diberi mulsa jerami yang menutupi penuh permukaan bedengan dengan ketebalan 10-15 cm. Seminggu setelah penanaman bawang merah, dilakukan penyulaman terhadap umbi bibit yang tidak tumbuh atau busuk. Bibit yang ditanam sama seperti bibit yang digunakan pada kegiatan kaji tindak di Dusun Bongor, yang merupakan umbi bibit hasil seleksi dan perbanyakan dari bibit stok. Aplikasi pupuk organik, pengendalian hama dan penyakit serta pengairan disesuaikan dengan komponen teknologi yang diterapkan pada kegiatan demplot sebelumnya.

Evaluasi dilakukan terhadap perubahan status kesuburan tanah, efisiensi pengairan yang dihitung berdasarkan volume air yang diberikan selama pertumbuhan tanaman terhadap hasil nyata (aktual) tanaman bawang merah. Berdasarkan hasil pengamatan dan analisis di laboratorium (Tabel 2), tampak bahwa perubahan status kesuburan tanah setelah aplikasi 
pupuk organi terjadi cukup signifikan terutama kandungan bahan organik tanah dan indek populasi cacing tanah. Kandungan NPK dan KTK-tanah tidal terjadi perubahan yang signifikan dan bahkan untuk N-total tanah, kandungannya lebih rendah dibandingkan dengan $\mathrm{N}$-total tanah pada areal tanamaman bawang merah yang diusahakan secara konvesional. Pengairan sejak pengolahan tanah, tanam, pemeliharaan sampai menjelang panen hanya dilakukan 4 kali, dengan waktu penyiraman selama 4,5 jam/ha. Total produksi bawang merah yang dapat dihasilkan 10,6 ton/ha. Sementara penanaman secara konvensional pengairan sampai 6 kali, dengan waktu penyiraman selama 6 jam/ha, dan total produksi bawang merah yang dapat dihasilkan hanya 8,941 ton/ha.

Tabel 2. Perubahan status kesuburan tanah dan hasil bawang merah, setelah aplikasi beberapa komponen masukan teknologi yang diintroduksikan

\begin{tabular}{lcc}
\hline No. Pengamatan variabel & $\begin{array}{c}\text { Sebelum aplikasi } \\
\text { masukan } \\
\text { teknologi }\end{array}$ & $\begin{array}{c}\text { Setelah aplikasi masukan } \\
\text { teknologi yang } \\
\text { diintroduksikan }\end{array}$ \\
\hline 1 Status kesuburan tanah & 7,70 & 6,51 \\
a. pH tanah & 2,42 & 4,43 \\
b. Bahan organik (\%) & 0,84 & 0,51 \\
c. N total (\%) & 2,41 & 2,46 \\
d. K2O ppm & 3,04 & 3,12 \\
e. P2O ppm & 11,46 & 11,86 \\
f. KTK (me/100g tanah) & 12,14 & 36,44 \\
g. Indeks populasi cacing tanah & & 9,124 ton/ha \\
\hline 2 Hasil bawang merah- & 8,344 ton/ha & 11,042 ton/ha \\
Musim Tanam I & 8,344 ton/ha & $10,61 \%$ \\
Musim Tanam II & & $9,24 \%$ \\
\hline Intensitas hama ulat grayak: & $14,71 \%$ & \\
Musim Tanam I & $20,23 \%$ & \\
Musim Tanam II &
\end{tabular}

Pada situasi lahan sawah yang dirancang sama, namun jika salah satu komponen masukan teknologi diabaikan, misalnya tanah tidak dipupuk dengan pupuk kompos atau pupuk organik, pertumbuhan bawang merah lebih jelek, dan setelah dievaluasi hasil yang diperoleh juga lebih rendah. Selain itu penggunaan air juga lebih boros, yang tercermin dari frekuensi penyiraman selama pertumbuhan tanaman, yaitu bila semua komponen masukan teknologi diterapkan penyiraman hanya $4 \mathrm{~s} / \mathrm{d} 5$ kali dengan waktu 4,5 jam/ha. Sementara itu dalam kasus ini 
penyiraman menjadi 5 s/d 6 kali dengan lama waktu $5 \mathrm{jam} / \mathrm{ha}$. Hasil rata-rata umbi bawang merah yang diperoleh pada kegiatan kaji tindak ini ternyata juga cukup tinggi pada petak contoh yang diberi pupuk organik dosis 25 ton/ha dengan produksi ratarata 9,124 ton/ha pada musim tanam I, meningkat sampai 11,042 ton/ha pada musim tanam II. Penyiraman menjadi lebih efisien pada tanaman yang diberi pupuk organik dibandingkan tanpa pupuk organik.
Dari hasil evaluasi pelaksanaan demplot secara menyeluruh, ternyata ada perbedaan keuntungan antara kedua lokasi demplot. Pada Tabel 3 tampak bahwa rata-rata pendapatan dan laba bersih tertinggi diperoleh pada aktivitas pengusahaan tanaman bawang merah musim tanam ke-II pada petani mitra di Dusun Peseng. Laba bersih yang terrendah diperoleh pada pengusahaan tanaman bawang merah musim Ke-I pada petani mitra di Dusun Bongor.

Tabel 3. Analisis biaya produksi, pendapatan, laba rugi, BC-ratio, BEP, dan efisiensi pengairan pengusahaan bawang merah oleh petani mitra di Dusun Bongor dan Peseng, Desa Kebunayu

\begin{tabular}{|c|c|c|c|c|c|c|c|c|}
\hline \multirow{2}{*}{$\begin{array}{c}\text { Tempat } \\
\text { Pengusahaan } \\
\text { \& Musim } \\
\text { Tanam }\end{array}$} & \multirow{2}{*}{$\begin{array}{l}\text { Biaya } \\
\text { Produksi } \\
\text { Rp/ ha } \\
(x 000)\end{array}$} & \multirow[b]{2}{*}{$\begin{array}{c}\text { Total } \\
\text { Produksi } \\
\text { ton/ha }\end{array}$} & \multirow{2}{*}{$\begin{array}{c}\text { Total } \\
\text { Pendapatan } \\
\text { Rp /ha } \\
\text { (x000) }\end{array}$} & \multirow[b]{2}{*}{$\begin{array}{c}\text { Laba } \\
\text { (Rp) } \\
(x 000)\end{array}$} & \multirow[b]{2}{*}{$\begin{array}{l}\text { BC- } \\
\text { Ratio }\end{array}$} & \multicolumn{2}{|c|}{ BEP } & \multirow[t]{2}{*}{ EPA } \\
\hline & & & & & & $\begin{array}{c}\text { BEP } \\
\text { produksi } \\
(\mathrm{kg})\end{array}$ & $\begin{array}{l}\text { BEP harga } \\
\text { (Rp) }\end{array}$ & \\
\hline \multicolumn{9}{|c|}{ Dusun Bongor } \\
\hline $\begin{array}{l}\text { Musim Tanam } \\
\text { Ke-I }\end{array}$ & 73.455 & 8,467 & 127.005. & 53.560. & 1,72 & 4.897 & 8.675,- & 2,76 \\
\hline $\begin{array}{l}\text { Musim Tanam } \\
\text { Ke-II }\end{array}$ & 73.996. & 10,244 & 153.360. & 79.364. & 2,07 & 4.933 & $7.223,-$ & 1,36 \\
\hline \multicolumn{9}{|c|}{ Dusun Peseng } \\
\hline $\begin{array}{l}\text { Musim Tanam } \\
\text { Ke-I }\end{array}$ & 73.500. & 9,124 & 136.860 & 63.360. & 1,86 & 4.900 & 8.055,- & 2,74 \\
\hline $\begin{array}{l}\text { Musim Tanam } \\
\text { Ke-II }\end{array}$ & 74.270. & 11,042 & 165.630. & 91.369. & 2,23 & 4.951 & $6.726,-$ & 1,17 \\
\hline
\end{tabular}

\section{Keterangan :}

1. Biaya produksi = Biaya sarana produksi + Biaya tenaga kerja + Biaya pengairan + Biaya tetap dan lain-lain

2. $\mathrm{BC}$-ratio $\quad=$ Total pendapatan: Total biaya produksi

4. BEP $_{\text {volume produksi }}=$ Biaya produksi : Asumsi harga produk

5. $\mathrm{BEP}_{\text {harga jual produk }}=$ Biaya produksi : Asumsi total produksi

6. Asumsi harga $=\operatorname{Rp} 15.000,-$

Tampaknya untuk bawang merah di Dusun Peseng. keberlanjutan proses produksi sistem Selain dapat memberikan laba bersih pola tanam seri planting yang yang tinggi, nilai BC-ratio menguntungkan sejak siklus tanam I pengusahaan bawang di wilayah sampai ke II adalah pengusahaan tersebut juga relatif lebih tinggi 
dibandingkan dengan pengusahaan di Dusun Bongor, yaitu untuk tanaman musim I dan II berkisar antara 1,86 2,36. Ini berarti bahwa setiap penambahan satu satuan biaya produksi untuk pengusahaan tanaman bawang merah di lokasi tersebut untuk musim tanam I dan II, akan diperoleh tambahan pendapatan 2,9 - 2,4 kali dari tambahan biaya produksi. Pengembalian nilai investasi (Break even poin), tercapai pada kondisi haraga seperti sekarang, yaitu Rp 15.000,-/Kg, jika produksi rata-rata per hektar mencapai, 4,90 - 4,95 ton/ha. Bila produksi bisa dipertahankan sampai mencapai kondisi sekarang yaitu rata-rata $9 \mathrm{~s} / \mathrm{d}$ 11 ton/ha, maka pengembalian nilai investasi (Break even point), tercapai pada kisaran harga $\mathrm{Rp} 6.726$ - Rp $8.055 / \mathrm{kg}$. Hal yang sama juga terjadi pada pengusahaan bawang di wilayah Dusun Bongor, bahwa baik nilai BCratio maupun BEP tidak menunjukkan perbedaan yang berarti. Ini berarti

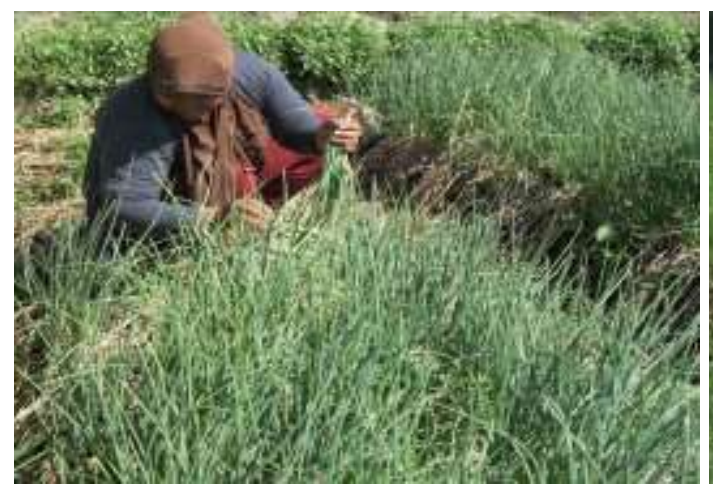

bahwa berapapun nilai investasi untuk penambahan biaya produksi tidak diperoleh tambahan ataupun pengurangan pendapatan yang berarti.

Karena hasil dari kegiatan kaji tindak dan demplot ini cukup berhasil dan dapat memberikan petani gambaran hasil yang nyata (Gambar 2 dan Gambar 3), maka beberapa petani mitra baru ada yang berminat masuk kelompok untuk menerapkan model usahatani bawang merah ekologis terpadu ini di lahan sawah mereka masing-masing. Untuk wilayah di Bongor, ada permintaan tambahan petani mitra baru 2 orang. Dusun Peseng ada permintaan tambahan petani mitra baru mencapai 4 orang. Tingginya minat petani mengembangkan model usahatani ini di Dusun Peseng diduga erat kaitannya dengan adanya fasilitas jaringan irigasi baru, sehingga petani dapat melakukan penanaman sepanjang musim.

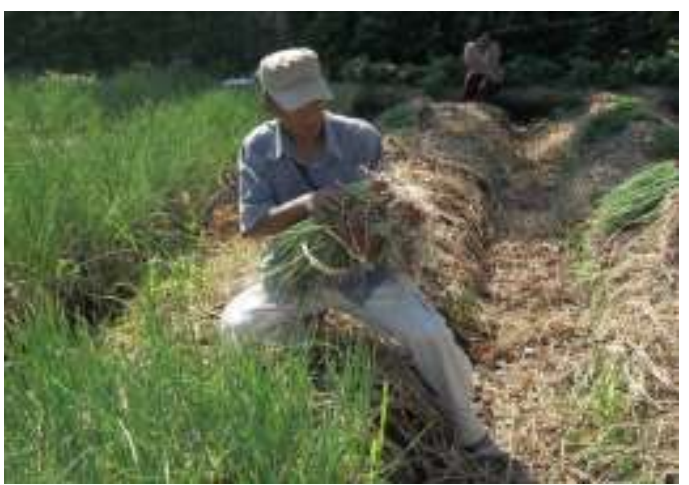

Gambar 2. Pertumbuhan tanaman yang baik akibat aplikasi pupuk orgsnik (Gambar kiri); dan Hasil panen yang cukup tinggi (Gambar kanan) 


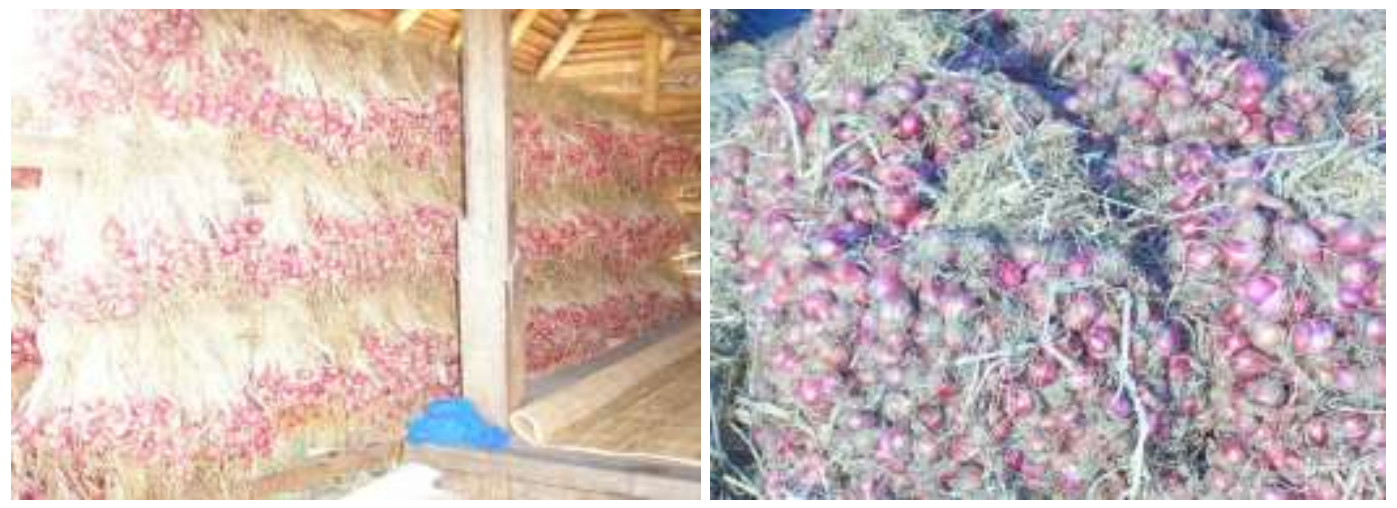

Gambar 3. Hasil bawang merah yang dikering anginkan dengan cara disangsang (Gambar kiri); dan hasil bawang merah yang telah siap dipasarkan untuk umbi bibit maupun konsumsi (Gambar kanan)

\section{KESIMPULAN DAN SARAN}

\section{Kesimpulan}

Berdasarkan hasil evaluasi
seluruh kegiatan pelatihan,
pendampingan dan pelaksanaan
demplot oleh petani mitra di
lahannya, diperoleh beberapa
kesimpulan sbb:

1. Hasil kegiatan kaji tindak berupa pelatihan dan praktek langsung penerapan teknologi produksi umbi bibit bawang merah oleh petani mitra di lahannya masingmasing menunjukkan bahwa model masukan teknologi yang diintroduksikan memberikan hasil dan keuntungan yang cukup tinggi, dan jauh lebih tinggi di lahan demplot petani mitra dibandingkan dengan di lahan petani non-demplot.

2. Melalui pelatihan dan pendampingan ini, petani mitra peserta demplot menjadi terampil dalam mengelola usahataninya dan menghitung biaya produksi dan keuntungannya.
3. Pelaksanaan demplot ini cukup berhasil dan dapat memberikan gambaran hasil yang nyata bagi petani, terbukti dari adanya petani mitra baru yang masuk kelompok mitra binaan untuk menerapkan model usahatani ekologis terpadu ini di lahan mereka masing-masing pada musim tanam II, yaitu 1 orang di Dusun Bongor dan 3 orang di Dusun Peseng.

\section{Saran}

Kegiatan ini perlu terus dilanjutkan, terutama penerapan beberapa komponen masukan teknologi berupa aplikasi dan pemanfaatan pupuk organik dari kandang sendiri dan penggunaan tanaman kacang-kacangan, terutama kacang tanah sebagai tanaman penangkal serangan hama dalam pengusahaan bawang merah pada sepektrum yang lebih luas, misalnya uji langsung terhadap hasil aktual dengan modal lebih banyak pada areal yang lebih luas dengan jangka waktu penerapan yang lebih lama, 
untuk membuktikan keberlanjutan dari model yang diintroduksi ii dalam jangka panjang.

\section{UCAPAN TERIMA KASIH}

Penulis mengucapkan terima kasih kepada Direktorat Penelitian dan Pengabdian Masyarakat, Kementerian Riset, Teknologi dan Pendidikan Tinggi yang telah memberi dukungan financial terhadap pelaksanaan kegiatan pengabdian kepada masyarakat ini, melalui skim $\mathrm{I}_{\mathrm{b}} \mathrm{M}$ pada tahun 2014.

\section{DAFTAR PUSTAKA}

Budianto, A., Sudika, I.W., Ngawit, I.K. 2008. Perbaikan Sifat-Sifat Unggul Bawang Merah Kultivar Ampenan melalui Seleksi Klon Berulang Sederhana dan Uji Adaptasi terhadap Kekeringan pada Sistem Pertanian Organik. Laporan Hasil Penelitian Hibah Bersaing. Ditjen Dikti.

Dinas Perindustrian dan Perdagangan Lombok Barat NTB, 2008. Data Perdagangan Antar Pulau Komoditi Hortikultura Kabupaten Lombok Barat. Humas Diperindag Tk. II Lombok Barat NTB, Girimenank Gerung.

Dinas Pertanian Tanaman Pangan NTB, 2008. Prospek Pengembangan Padi, Palawija dan Sayur-sayuran dan Buah- buahan di Pulau Lombok. Humas Diperta Tk.I NTB, Mataram.

Kusnarta, I.G.M. 1996. Evapotranspirasi dan hasil tanaman jagung pada berbagai dosis pupuk kandang dan mulsa. Agroteksos, 6(3): 152-158.

Kusnarta, I.G.M., Tarudi, H.M., Silawibawa, I.P., Idris, M.H. 1998. Kajian Usahatani Konservasi dengan Budidaya Lorong Menggunakan Tanaman Buah Serikaya (Annona squamosa L.) dan Legum. Laporan Hasil Penelitian Dosen Muda. Fakultas Pertanian Universitas Mataram.

Ngawit, I.K., Irasakti, L., Farida, N. 1998. Efek pemberian pupuk kandan dan Kalium secara bertahap terhadap pertumbuhan dan hasil kedelai di lahan kering wilayah pengembangan Lombok Utara. Laporan Hasil Penelitian P2SLPT, Ditjen Dikti.

Ngawit, I.K., Irasakti, L., Abdurrachman, H. 2000. Efisiensi Penggunaan Irigasi Air Tanah dalam Upaya Peningkatan Produktivitas Lahan Kering dan Pendapatan Petani Jagung di Kecamatan Bayan, Lombok Barat, NTB.

Wood, C.W., Edwards, J.H., Cummins, C.G. 1992. Tiilage and crop rotation effect on soil organic matter in a typical hapludult of Northern Alabama. J. Sustain. Agric., 22: 31-41. 